\title{
Canadian Historical Writing
}


This page intentionally left blank 


\title{
Canadian Historical Writing \\ Reading the Remains
}

\author{
Renée Hulan
}




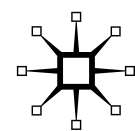

CANADIAN HISTORICAL WRITING

Copyright (c) Renée Hulan, 2014.

Softcover reprint of the hardcover 1st edition 2014 978-1-137-39888-8 All rights reserved.

All references to material held in the Timothy Findley fonds at the National Archives of Canada. Used by permission of William Whitehead and Pebble Productions Inc.

All references to material held in the Margaret Atwood Papers at the Thomas Fisher Rare Book Library, University of Toronto. Used by permission of Margaret Atwood.

Letter from Dr. Ramsay Cook to Margaret Atwood held in the Thomas Fisher Rare Book Library. Used by permission of Dr. Ramsay Cook.

Poems by Marilyn Dumont, from the publication A Really Good Brown Girl published by Brick Books, London Canada. Used by permission of the publisher.

Poems by Armand Garnet Ruffo, from the publication Grey Owl: The Mystery of Archie Belaney published by Coteau Books, Regina Canada. Used by permission of the publisher.

Poems by Armand Garnet Ruffo, from the publication Opening in the Sky. Used by permission of Armand Garnet Ruffo.

First published in 2014 by PALGRAVE MACMILLAN ${ }^{\circledR}$ in the United States-a division of St. Martin's Press LLC, 175 Fifth Avenue, New York, NY 10010.

Where this book is distributed in the UK, Europe and the rest of the world, this is by Palgrave Macmillan, a division of Macmillan Publishers Limited, registered in England, company number 785998, of Houndmills, Basingstoke, Hampshire RG21 6XS.

Palgrave Macmillan is the global academic imprint of the above companies and has companies and representatives throughout the world.

Palgrave ${ }^{\circledR}$ and Macmillan ${ }^{\circledR}$ are registered trademarks in the United States, the United Kingdom, Europe and other countries.

\section{ISBN 978-1-349-48562-8 ISBN 978-1-137-39889-5 (eBook) \\ DOI $10.1057 / 9781137398895$}

Library of Congress Cataloging-in-Publication Data

Hulan, Renée.

Canadian Historical Writing : Reading the Remains / Renée Hulan. pages $\mathrm{cm}$

Includes bibliographical references.

\section{Canadian literature-}

History and criticism. 2. Historiography-Canada-History. 3. Literature and history-Canada—History. I. Title.

PR9185.2.H84 2014

$810.9^{\prime} 971-\mathrm{dc} 23$ 2013049617

A catalogue record of the book is available from the British Library.

Design by Scribe Inc.

First edition: June 2014

$\begin{array}{llllllllll}10 & 9 & 8 & 7 & 6 & 5 & 4 & 3 & 2 & 1\end{array}$ 
For Rebecca and her dad 
This page intentionally left blank 


\section{Contents}

Acknowledgments $\quad$ ix

Preface xi

1 From Romance to Revision: Historical Writing in Canada 1

2 Timothy Findley and the Burdens of Metahistory 37

3 Margaret Atwood in Search of Things Past 71

4 Armand Garnet Ruffo and the Persistence of Memory 103

Epilogue 137

$\begin{array}{ll}\text { Notes } & 145\end{array}$

$\begin{array}{ll}\text { References } & 175\end{array}$

Index 193 
This page intentionally left blank 


\section{Acknowledgments}

The preliminary research for this book was conducted with the financial support of the Social Sciences and Humanities Research Council of Canada, which funded the archival research as well as the research assistance of excellent students at various stages of this project, including Megan Clare, Heather Egger, Kendall Shields, and Peter Thompson, and thanks to Stephanie Moulton for preparing the index. My heartfelt thanks to the ever-generous William Whitehead for encouraging me and granting access to the Timothy Findley fonds held at the National Archives of Canada, to Margaret Atwood for access to her papers at the Thomas Fisher Rare Book Library at the University of Toronto, and to Laura Stenberg at O. W. Toad. Thanks especially to the staff at the Thomas Fisher Library and to Anne Goddard for her assistance at the National Archives. At Palgrave, Brigitte Shull's care and attention to the manuscript, as well as the organizational skills of her assistant Ryan Jenkins, were crucial to completing the project. Thank you to the anonymous reader for the insightful and helpful comments on the manuscript. For encouragement that never wavers, I am particularly grateful to Shelley Hulan, Nicole Neatby, and Michael E. Vance. 
This page intentionally left blank 


\section{Preface}

To those in power, history has always mattered.

— Gerda Lerner ${ }^{1}$

Canadian Historical Writing: Reading the Remains began as a study of contemporary Canadian historical fiction. As a reader and professor who began teaching Canadian literature full time in the late 1990s, I wanted to understand the relationship between the proliferation of historical novels at the time and developments in late twentieth-century historiography. In both the academy and the mass media, the role of history in public life was the subject of intense debate. Literary criticism was grappling with what seemed to be a sudden turn to the historical novel by Canadian authors, and historians were evaluating the use of fictional techniques in the writing of history. As I followed these discussions, I learned that the issues arising from historical representation troubling literary scholars were being energetically debated by historians as well. The more I read, the more convinced I became that literary study can benefit from the insights derived from contemporary historiography, especially after the linguistic turn. The rich potential of such interdisciplinarity already informed research on early Canada as exemplified by the work of such prominent scholars as Carole Gerson and I. S. MacLaren who were using historical method to interpret literary works. Yet while historians and philosophers of history often embraced insights gained from literary theory, particularly narrative theory, there had been comparatively few investigations of historiographical theory in the literary criticism of contemporary fiction where "History" was often invoked either to signify the naïve belief that the past could be represented "as it actually happened" or to adhere to master narratives constructed to preserve unequal power relations. By representing the historical field as essentially unchanged since the time of Leopold von Ranke, literary criticism could reproduce, often uncritically, the analysis of nineteenth-century historicism in the work of Hayden White; indeed, even now, White's arguments continue to be reiterated without regard for their own historical context, indicating that more interdisciplinary work remains to be done. 
Creating interdisciplinary dialogue between historians, literary critics, and the historical novelists they study, as I hope to do with this book, brings to light similarities that the often-antagonistic approach to history in literary criticism tends to downplay. By considering the role of historical research in shaping the writer's historical consciousness, the essays in this book compare fiction writing to the historian's craft. Reading in this way is meant to return attention to the literary work as a made thing crafted by a writer. While fiction writers and historians share the practice of historical research, their methods can be profoundly different. It may be a truism that the absence of documents presents a "quandary" for historians and an opportunity for creative writers, but the difference in the disciplines is most apparent when confronting the issue of documentary remains. For historians, a plausible account of the evidence hinges on determining the authenticity of sources. This is what the philosopher Paul Ricoeur calls "the referential moment that distinguishes history from fiction," and it is why he argues that the study of literary forms alone cannot adequately address memory, history, and forgetting. ${ }^{2}$ Creative writers also rely on the referentiality of the source in order to create a fictional world, though analysis of this aspect of the writer's craft has been limited to the reality effect. When searching for the aesthetic form in which to create a sense of the past, writers of fiction draw on research into historical materials as part of the creative process. Even though writers of historical fiction are not constrained by the rules of evidence that guide historians, the voluminous evidence of research in the archives and the scrupulous acknowledgments in contemporary historical novels show not only that writers generally conduct research on the subjects they write about but that they also treat documents as source material with authority and validity that must be assessed and interpreted. While both the fiction writer and the historian read the remains of the past, they differ in what they consider evidence and how they use it. ${ }^{3}$

Canadian Historical Writing: Reading the Remains has been inspired by archaeological approaches that aim to uncover layers of context surrounding the literary artifact. In addition to reading contemporary Canadian historical fiction in the context of contemporary historiography, the book attempts to understand the self-conscious turn to the historical at the end of the twentieth century by studying examples of Canadian historical fiction. By placing the perceived return to history in theoretical and historical context, it also seeks to address the anxiety surrounding historical knowledge in late twentieth-century Canada. When I started teaching full time in the late 1990s, I became responsible for general courses in the field in addition to courses based on my work on the North and on writing by Aboriginal authors, and while remaining committed to those areas of research, I 
also found myself studying the work, and soon after, the archives, of historical novelists. I began thinking about historical fiction as a genre closely related to historiography, and therefore, when planning this book, I chose works that, to my mind, would represent the broad trends in Canadian historical fiction reflecting changes in historiography generally. As a result, the selection of authors reflects when this project was undertaken. While these examples are by Canadian authors, the method used in the following essays, which emphasizes the role of evidence in the writer's method and craft, seeks to uncouple the nation-history dynamic framing discussions of historical fiction. The works selected are therefore not meant to represent Canadian historical fiction as a whole or to offer regional coverage; instead, each one serves as a case study of a particular moment in Canadian literary history.

As the discussion moves back in literary history, recovering context relies on archival documents, a method derived from Michel Foucault's insights into the repression of difference underlying the history of ideas. In the resistance to coherence and attention to discontinuity, contradiction, and absence that was his challenge to the Annalistes, Foucault displaced the study of mentalites and introduced a way of approaching the past whose influence on historiography can be readily seen in theory and practice. ${ }^{4}$ This influence is articulated in Ian Hodder's classic introduction to the study of archaeology, which grounds the method of interpretation in an awareness of the observer's subjectivity and respect for the different subjectivities of people in the past: "Since the past cannot be known with certainty, we do not have the right to impose our own universals on the data and to present them as truth." ${ }^{\prime}$ Hodder's aim was to reveal how archaeological method is both theory-dependent and bound by a reality that is independent: "Whatever our perceptions or worldview," he writes, "we are constrained by the evidence, and brought up against its concreteness." 6 The meaning archaeologists strive for is obtained by reading a part, often an object, in relation to a whole context so that the remains of a society's material culture articulate the actions of people living in that society: "The task of archaeologists is to interpret this irreducible component of culture so that the society behind the material evidence can be 'read.' As soon as the context of an object is known it is no longer totally mute." ${ }^{\prime 7}$ Like archaeologists, many historians and writers of historical fiction also look to voice the experience of the silent, especially those whose race, gender, or class has excluded them from historical narratives. To read literary texts, especially works of historical fiction, as artifacts means to consider them in their literary context and to derive meaning from their relationship to other texts in the interdiscursive reading Foucault made possible, though perhaps without his deep skepticism of historical reconstruction. Rather 
than the relentless and futile search for origin that Foucault identified, the reconstructed context forms a hypothesis, a point of investigation and dialogue, and a return to the material conditions to which that context refers. In this study, the material context is accessed and reconstructed from published studies in historiography and intellectual history; critical essays, reviews, and interviews forming the critical reception of selected literary works; and documents held in individual authors' archives. The essays bring these sources together around four themes relating to the matter of history: nation, interpretation, evidence, and time. As captured in Gerda Lerner's Why History Matters, which is a touchstone for this book, attending to these themes recalls the history repressed by nationalist narratives aligned with power. Recently, the issues surrounding how history matters have taken on a new urgency in Canada.

In the summer of 2012, communities across Canada marked the bicentennial of the War of 1812. The federal Conservative government had announced its intention to celebrate the occasion in the 2011 speech from the throne: "Beyond our natural heritage, Canadians also cherish our shared history. Anniversaries are an important part of how a society marks its collective progress and defines its goals for the future. A key milestone next year will be the bicentennial of the War of 1812. We will remember how those of diverse backgrounds and various regions came together to fight for Canada, ensuring the independent destiny of our country in North America." ${ }^{8}$ As these remarks indicate, the bicentennial would be celebrated as a Canadian victory, "the war that forged a nation" as the subtitle of Walter Borneman's historical account proclaims, ${ }^{9}$ rather than a colonial war fought on the periphery of empire. Never mind that Canadian nationalism did not exist in 1812. Never mind American victories such as the Battle of New Orleans. The War of 1812 is recast as a moment of "Canadian" triumph. The nationalist argument underlying these claims bases the existence of present-day Canada on the territorial boundaries established at the end of the war. As the Government of Canada presented it, British, French, and Native fought side by side, putting aside their differences for their mutual good. With individual historical figures like Tecumseh and Laura Secord to celebrate, the story of the War of 1812 could project democratic values into a past where racial and gender equality were unknown. The narrative of the unified, egalitarian, protomulticultural nation fighting for its freedom masks a historical revision that, as Ian McKay and Jamie Swift have recently shown, ascribes the creation of present-day Canada to military conflict. In historical terms, this revision borders on utter fantasy, but it has undeniable utility for a government that dispensed an estimated \$35 million in what McKay and Swift call "a multimillion-dollar propaganda push aimed at flogging a cardboard version 
of history, painting the foolish, inconclusive War of 1812 in patriotic colours." ${ }^{10}$ That this extravagant spending occurred as Canadian war veterans were going to court to make the Government of Canada live up to its commitments, ${ }^{11}$ and as annual funding for the National Parks where commemorative events were held was being slashed, ${ }^{12}$ demonstrates just where government priorities lie.

Government-funded events were held in cities and towns across Canada, but most were staged around the sites of battles in which the British forces prevailed, mostly in suburban southern Ontario, a decisive region in the federal election in 2011. The Niagara region enjoyed a large share of this funding with $\$ 9$ million to be spent on Old Fort Erie, McFarland House, and the Laura Secord homestead, and the provincial and federal governments each gave $\$ 3.2$ million to renovate the History Museum at Niagara Falls. An estimated 700 reenactors participated at Niagara's Siege Weekend festivities, attracting approximately 2,000 visitors to the Old Fort. Readers of the Hamilton Spectator were invited to "Relive War of 1812 inside mall tent" on June 15, 2012. The event, sponsored by the Stoney Creek Battlefield Museum, featured a replica 1812 wedge tent, a display of postcards made by local seventh grade students, and "battle re-enactors in full military uniform."13

Ironically, the narrative of Canadian national independence created for this war's bicentennial was represented at many of the celebrations by mimicking a staple of American popular culture, the historical reenactment. As David Lowenthal observes: "In the United States, re-enactments are a sine qua non of popular participation in history. Scarcely a skirmish of the Revolution went unrepeated during the 1976 bicentennial celebrations. Many battle participants spend large sums on equipment and uniforms, wax fanatical over details of dress down to the contents of their pockets, and designate 'historians' to research battles and troop movements." 14

As Lowenthal notes, reenactors crave authenticity, which they go to great lengths to display by researching every small detail of the costumes and props needed to stage a particular event. As one reenactor at Niagara put it, dressing up and playing soldiers can be "a lot of fun." The preoccupation with the larger picture is often not represented in these reenactments, but the patriotic celebration of the War of 1812 has more to do with nineteenth-century historical and literary representations than geopolitics. After Confederation, the War of 1812 was a featured setting in historical romances looking to the past for narratives of national origin, and historical figures, including Tecumseh and Laura Secord, were idealized in poetry and prose. Today's promoters of Canadian nationalism are working in the same vein but with a different purpose. 
What happened to the commemoration ceremony at Queenston Heights represents Canadian society more accurately than the reenactment's script. Days before the event, the representatives of the Six Nations Confederacy announced that they would not take part. The group from the Six Nations, which included the Haudenosaunee Confederacy and elected band council as well as a men's and women's singing group and a group of young dancers, had planned to present the wampum belt given to them in recognition of their alliance during the War of 1812. "It was an opportunity for us to renew pledges. We have an alliance. We are allies and we entered this agreement and we have honoured this agreement," director of the Six Nations consortium, Keith Jamieson, told the Hamilton Spectator. When the event organizers scheduled the Six Nations to arrive after the Governor General finished his speech and left the stage, it was an insult, as Jamieson remarked, explaining the group's intention to reaffirm its historic relationship with the Crown: "What's the point now? Just to be dancing and singing Indians?" 15 The Six Nations withdrew from the event.

The program suggests that the event organizers viewed the Mohawk as decorative details in the pageant. The peripheral role assigned to the Six Nations at the commemoration betrays a shocking lack of historical knowledge when the military history of the war shows that few of the British victories could have occurred without Aboriginal warriors. In Canada's First Nations, Olive Dickason emphasizes the differing interpretations of the War of 1812: "For Britain and the US it was an inconclusive contest that left important matters, such as those relating to Amerindians, as unresolved as they had been before the fighting; for the Amerindians, it was a turning point, as it was the last conflict in northeastern North America in which their participation was important and even decisive." The War of 1812 was neither foolish nor inconclusive for Britain's Native allies. At the Battle of Queenston Heights in particular, the Six Nations repelled the American attack "when they appeared at a critical moment on the field of battle led by the Mohawk Major John Norton (Teyoninhokerawen, $f$. 1784-1825) and John Brant ('Tekarihogen', Ahyonwaeghs, 1794-1832), the youngest son of Joseph Brant."16 Across the north and west, Tecumseh's warriors and their allies made the difference, a fact that the British recognized immediately after his death by "trying to enshrine Tecumseh's memory as an icon" and by rewarding his family members. ${ }^{17}$ As a result, Tecumseh is remembered for loyalty to the British cause and not for his achievements as a diplomat capable of bringing together a powerful alliance of First Nations.

As Paul Ricoeur warns, the excess of memory of some events leads inevitably to forgetting others. The celebration of the bicentennial of the War of 1812 as a moment of national becoming seeks to reshape Canadian society 
by aggrandizing selected historical events while ignoring, denying, or revising historical evidence. It is part of a general assault by the Government of Canada on all forms of empirical knowledge from census data to the science of climate change and leading to the funding cuts that are dismantling institutions like the National Library and Archives of Canada.$^{18}$ Many of the historical novelists writing today are dedicated to what Ricoeur calls a "just allotment of memory," and while some might shrug off the preoccupation with the accuracy of detail that inspires historical reenactment, probably none of them would deny the reality of climate change-and all of them respect and conduct historical research. Historical writing that renders an aesthetic experience of the past does not merely create an illusion of reality as some might suggest, nor is it necessarily the death rattle of History as others may claim; rather, as I argue in the chapters that follow, it is the dialectical relation of material evidence and imagination that gives expression to historical consciousness. Canadian Historical Writing: Reading the Remains seeks the historically grounded analysis of this dialectic that reveals the consciousness motivating and animating literary works about the past. 